\title{
Power, identity and biodiversity conservation in the Montes Azules Biosphere Reserve, Chiapas, Mexico
}

\author{
Leticia Durand ${ }^{1}$ \\ Universidad Nacional Autónoma de México, Mexico
}

\begin{abstract}
In this article, I analyze how daily conservation discourse and practices create and recreate local identities through the reconfiguration of social relationships brought about by conservation encounters. The mobilization of identity has been a main strategy of the inhabitants of the Lacandon Community Zone and the Montes Azules Biosphere Reserve for maintaining their access to natural resources and benefitting from conservation. In the Lacandon Rainforest, conservation comes at great cost to the local population but, at the same time, offers an opportunity to access monetary and political resources. Because of this tension, the peasants build complex and fractured identities, in an iterative process, assuming different images as they struggle to reconcile their personal desires with the external plan to preserve the forest. Identity in the Lacandon Rainforest, as in other regions impacted by this practice, is a tool in the political struggle.
\end{abstract}

Keywords: identity, power, biodiversity, conservation, protected areas, Mexico

\section{Résumé}

Dans cet article, j'analyse comment le discours et les pratiques de conservation quotidiens créent et recréent des identités locales à travers la reconfiguration des relations sociales induites par les rencontres de conservation. La mobilisation de l'identité a été l'une des principales stratégies des habitants de la zone communautaire Lacandon et de la réserve de biosphère de Montes Azules pour maintenir leur accès aux ressources naturelles et bénéficier de la conservation. Dans la forêt pluviale de Lacandon, la conservation coûte très cher à la population locale mais offre également la possibilité d'avoir accès à des ressources monétaires et politiques. En raison de cette tension, les paysans construisent des identités complexes et fracturées, dans un processus itératif, en supposant que le plan d'images différentes dans leur lutte pour concilier leurs désirs personnels avec l'extérieur pour préserver la forêt. L'identité dans la Lacandon Rainforest, comme dans d'autres régions touchées par cette pratique, est un outil dans la lutte politique.

Mots-clés: identité, puissance, biodiversité, conservation, aires protégées, Mexique

\section{Resumen}

En este trabajo analizo cómo los discursos y la práctica cotidiana de la conservación crean y recrean las identidades locales a partir de la reconfiguración de las relaciones sociales que se producen en los encuentros de conservación y cómo, la movilización de la identidad ha sido una estrategia central de los habitantes de la Comunidad Zona Lacandona y de la Reserva de la Biosfera Montes Azules para mantener su acceso a los recursos naturales y beneficiarse de la conservación. En la Selva Lacandona, la conservación representa fuertes costos para la población local, pero al mismo tiempo, oportunidades para acceder a recursos financieros y políticos. Debido a esta tensión, los campesinos construyen identidades complejas y fracturadas, en un proceso iterativo, y asumen imágenes diferentes a medida que luchan por conciliar sus anhelos personales con el

\footnotetext{
${ }^{1}$ Dr. Leticia Durand, Research Professor, Centro Regional de Investigaciones Multidisciplinarias, Universidad Nacional Autónoma de México, Cuernavaca, Morelos, México. Email: leticiad "at" unam.mx. I owe special thanks to the Department of Geography at the University of British Columbia, Vancouver, where I wrote this article, for hosting me as a visiting scientist between 2014 and 2015. I am grateful to Juanita Sundberg for her support and comments on the manuscript, and to all the people in the Lacandon Rainforest who share their stories with me. This article has benefitted considerably from the comments of two anonymous reviewers. This work was supported by CONACYT [232898 Fondo I0010] and PASPADGAPA-UNAM.
} 
designio externo de preservar la selva. La identidad en la Selva Lacandona es, al igual que en otras regiones impactadas por esta práctica, una herramienta de lucha política.

Palabras clave: Identidad, poder, biodiversidad, conservación, áreas protegidas, México

\section{Introduction}

In the Vancouver Subway during the summer of 2014, one could see advertisements encouraging people to visit Chiapas, a state in south-east Mexico. The posters were part of the campaign Visit Mexico, created by the Mexican government to promote the country as a tourist destination. With photographs of the Palenque ruins and jaguars in the tropical rainforest, the adverts invited Canadians to view nature and the indigenous cultures of Chiapas. Many of these attractions, however, are located in a beautiful but socially restless region: The Lacandona Rainforest (LR). According to historian Jan de Vos (2005: 9) "...in no other region of the country have there ever been changes so profound and so drastic"; one of the greatest and most recent transformations for the LR has been its conversion to a region dedicated to conservation.

The LR is located in eastern Chiapas, bordering Guatemala; it is the largest remnant of tropical rainforest in North America, and one of the most biodiverse regions in Mexico (Figure 1) (Mendoza and Dirzo 1999). The LR had an area of 1,818,054 hectares and a population, in 2010, of 479,877, of whom $81 \%$ are poor and almost $70 \%$ indigenous, mainly from the Tzeltal, Tzoltzil, Chol, Lacandon and Tojolabal ethnic groups (Burguete Cal y Mayor 2013; INEGI 2012; Leyva Solano and Ascencio Franco 2002; Muench 2008). Chiapas, as described by Benjamin (1989) is a "rich land of poor people", where a violent political system, dominated by white elites, has maintained strong economic inequality for centuries.

The "last refuge" (Sarukhán 1991) or "the most important natural wonder of Mexico" (Carabias 2009) are expressions commonly used to refer to the LR, highlighting the importance of the natural attributes of the place; however, its social and cultural factors are disregarded. In the past, the area was called Desierto Lacandón (Lacandon desert) alluding to a vast, uninhabited green piece of land. Today, however, the LR is a densely populated, culturally diverse and socially complex region (de Vos 2005). The commercial exploitation of natural resources started in the mid $19^{\text {th }}$ century with the extraction of precious timber. It was not until the 1960s when a rapid process of deforestation began as a result of cattle ranching, forestry businesspeople and peasants ${ }^{2}$ who, often with government incentives, arrived in the rainforest seeking land and money. Fifteen years later, around 122,000 hectares of forest had been lost (O'Brien 1998). The government, trying to regain control over the forest and stop the expansion of the agricultural frontier, implemented several regulations. One of the most important was the creation of protected areas (PAs), a policy which began in Mexico around 1900 and gained track in the mid-1970s with the Man and the Biosphere Program (MAB-UNESCO) (Garcia Frapolli et al. 2009). Today PAs comprise more than 450,000 hectares of the LR; Montes Azules Biosphere Reserve (MABR) is 331,200 hectares in size, and is the main one in the region (INE 2000; Muench 2008; Trench 2008a; Tejeda Cruz 2009).

Due to the neoliberalization of environmental governance in Mexico, the government facilitates the use of land for exclusionary protection and natural resource exploitation by private actors including investors, conservation organizations, agricultural and tourist industries (Rocheleau 2015). As a result, evictions and land grabs have been reported in LR since the 1990s (Durand 2014; Rocheleau 2015). Reactions from those directly affected are complex and varied. Resistance is present, but also cooperation and integration into neoliberal biodiversity conservation schemes such as ecotourism, biofuel plantations and payment for ecosystem services, in which local communities, the government and private companies participate (Calleros Rodríguez 2014; Castellanos Navarrete and Jansen 2015; Igoe and Brockington 2007; Rocheleau 2015). Conservation policies have changed the cultural, economic and political dynamics of LR communities. People have been relocated and lost access to part of their lands, some communities became illegal settlements after PA creation, traditional

\footnotetext{
2 According to Van der Ploeg (2010) peasants are smallholders, usually poor who orient their production to selfprovisioning. The struggle for autonomy and the construction of a self-governed resource base that allows for co-production also characterize the peasantry in the 21 st century.
} 
resource use practices like slash and burn agriculture are discouraged by authorities and new clientelist relationships between the government and indigenous communities emerged (Legorreta Díaz et al. 2014; Tejeda Cruz and Márquez Rosano 2006; Trench 2008a). However, little is known about how people mobilize their identities, even though identity is a key factor that shapes reactions "from below" to the enclosure of natural resources (Hall et al. 2015; Trench 2008a). The aim of this article is to understand how indigenous inhabitants of the Comunidad Zona Lacandona (Lacandon Community, LC) in the LR, a big part of the MABR, comprehend, incorporate and reconfigure conservation discourses and practices, and how their identities are continually reformulated in this process, in order to take advantage of the opportunities that conservation offers, while simultaneously maintaining their autonomy and control over their lives (Porro et al. 2011; Sundberg 2002; Vatjuniec et al. 2011a). To show how identities are constituted through struggles over nature and natural resources, and how the discourse and practice of conservation influence social difference, I adopt a political ecology perspective by placing attention on power relations in what Sundberg (2006), as explained below, calls "conservation encounters."

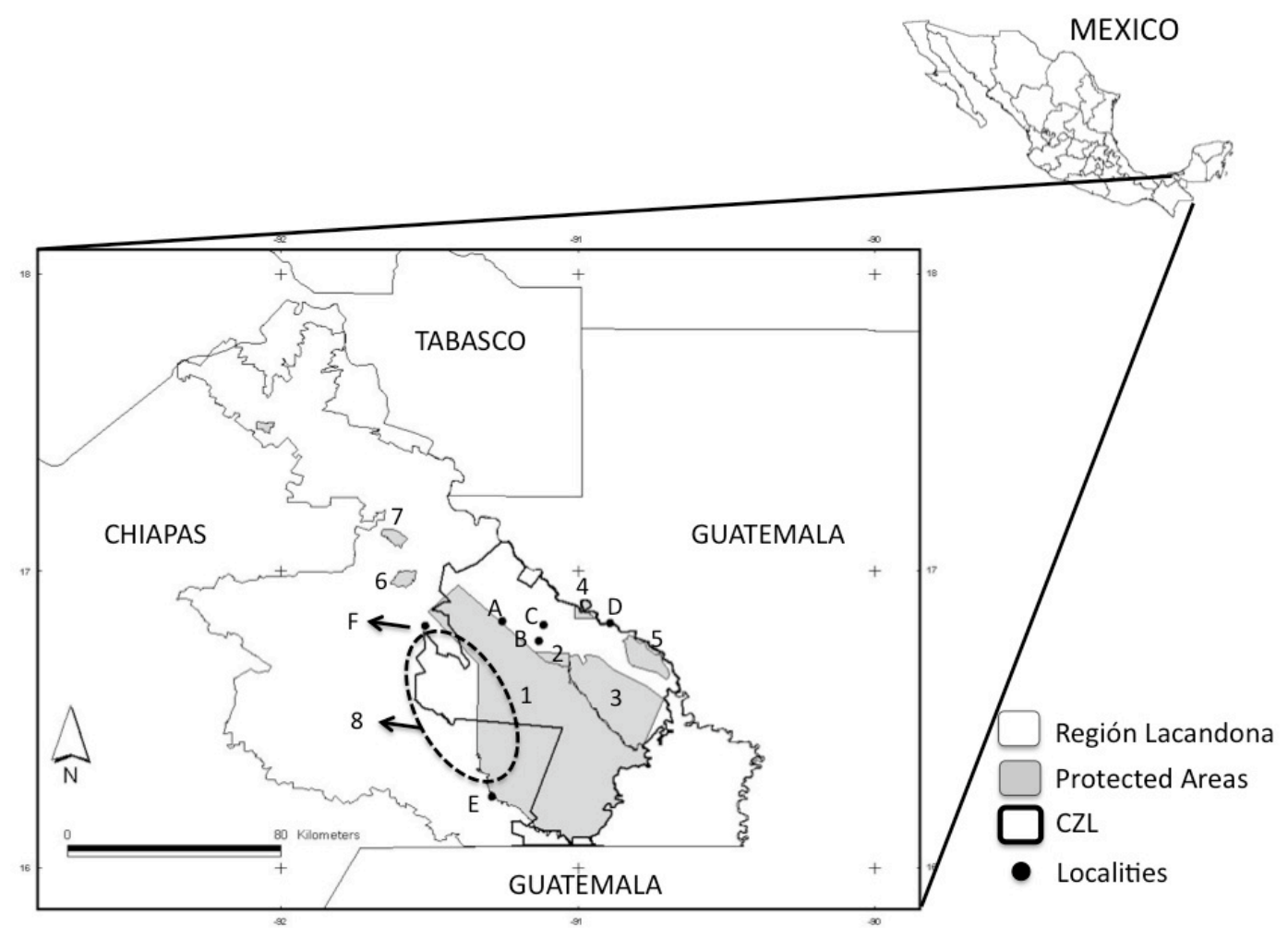

Figure I. Lacandon Rainforest Region. Protected Areas: 1. Montes Azules Biosphere Reserve. 2. Bonampak Natural Monument. 3. Lacantun Biosphere Reserve. 4. Yaxchilán Natural Monument. 5. Chan Kin Flora and Fauna Protection Area. 6. Nahá Flora and Fauna Protection Area. 7. Metzabok Flora and Fauna Protection Area. 8. Las Cañadas Region. Communities: A. Nueva Palestina, B. Lacanjá Chansayab, C. San Javier, D. Frontera Corozal. E. La Democracia. F. Agua Azul. Source: Durand et al. 2014.

\section{Identities and conservation in the MABR: theory and methods}

The Lacandons, speakers of Yucatec Maya, have inhabited the LR since the $17^{\text {th }}$ century. They arrived from the nearby regions of El Petén and Campeche, escaping from the violence and diseases brought by the Spanish conquerors. Lacandons were semi-nomadic and lived in small family groups called caribales; with a 
rich understanding of the forest they subsisted for centuries using a slash and burn system called milpa ${ }^{3}$ to cultivate maize, beans, cabbage, pepper and other crops (de Vos 2004; Levy Tacher and Duncan Colier 2004). By the mid $20^{\text {th }}$ century, the LR still was a vast forest and uninhabited area, but surrounding it, Tzeltal and Chol indigenous people took land. Tzeltals came to the LR mainly from adjacent municipalities such as Ocosingo, Altamirano and Las Margaritas, where large landholdings or fincas owned by powerful mestizo families from Chiapas began to drive the change from subsistence farming, based on coffee and maize, to extensive cattle-ranching, an activity which demands a smaller workforce (Ascencio Franco 2004; Paladino 2005). Chols arrived mostly from Tilá, Tumbalá and Sabanilla municipalities in the north of the State, where fincas belonging to foreign owners were dismantled after the agrarian reform. Influential mestizo peasants created new ejidos on those lands, displacing Chols from the area (Paladino 2005). Indigenous families expelled from the fincas were pushed to the LR by the government, which opened unsettled lands to peasants and encouraged cattle ranching as an option to transform the unproductive virgin forest into profitable pasture lands (Ascencio Franco 2004; de Vos 2005; Paladino 2005). Deforestation was also hastened by forest companies like Maderera Maya, founded in 1951 (de Vos 2004). The Tzeltal and Chol settlers who founded the communities of Nueva Palestina and Frontera Corozal, where this study was conducted, arrived to the LR between 1950 and 1960, while the Lacandon community of Lacanja Chansayab was established in 1957 when Philip Baer, a missionary of the Summer Institute of Linguistics, brought together some Lacandon family groups that lived in the area (Trench 2002).

By overlooking the intricate history of the recent colonization of LR, biodiversity conservation, as a narrative, tends to produce simplified images of indigenous people (Brosius 1999; Escobar 1998; Milton 1996; Nygren 2006). Even though Lacandons did not inhabit the area in pre-Hispanic times, they are seen as the last survivors of the ancient Mayas, and have become a sort of "ecological noble savage." Within the dominant conservation discourse in Mexico and Chiapas, and due to the depth of their environmental and agricultural knowledge, the Lacandons are often portrayed as innate environmentalists who fight to preserve the rainforest (Contreras Cortés et al. 2013; Trench 2002, 2005). In contrast Chols, Tzeltals and Tzotzils who occupied vacant lands in LR decades ago, are regarded as trespassers and destroyers (Trench 2005, 2008a; de Vos 2010). For example, during an interview in his office in Mexico City, an expert on the region and a high official of the National Commission for Protected Areas (CONANP), explained:

...Within the indigenous world in Mexico there are great differences, [some] groups have acted coherently, such as the Lacandons, who have always been few, who use the ecosystem well. But there are other groups, Tzeltzals and Tzotzils, who reproduce differently, use the environment differently and will eliminate the Lacandons, by absorbing them genetically, or doing away with them, just because they need land. ${ }^{4}$

In this testimony, some indigenous groups are considered to have ecological awareness and others as incapable of implementing appropriate productive practices; identity is separated from the social relationships that produce it, and stereotyped images of indigenous people are created. The production of these images has concrete effects: Lacandons receive most of the available funding for conservation, as well as most other economic benefits resulting from protected areas, and their opinions regarding the rainforest are viewed as authoritative. Meanwhile, the rest of the indigenous groups occupy a subordinate position (Rocheleau 2015; Trench 2008a; Villalobos Cavazos 2012).

Stereotyped images assign coherent and stable identities, ignoring heterogeneity within social groups, and they fail to consider all the practices, interactions, conflicts and alliances that are created through conservation projects, which constantly challenge and transform the way people perceive themselves and others. Therefore, identity construction is an iterative and continuous process through which individuals and

\footnotetext{
${ }^{3}$ A milpa is a traditional productive system in which maize is cultivated simultaneously with other crops such as beans, squash and peppers.

${ }^{4}$ CONANP Official, Mexico City. February 2009.
} 
social groups come to be in a particular place and time (Fearon 1999; Porro et al. 2011; Sundberg 2004). To overcome the idea of identity as fixed attribute, I use the idea of identity proposed by Tania Li (2000), for whom it is a positioning resulting from an ongoing process of meaning and historically sedimented practices in specific geographic areas. Identity is produced in specific contexts of social interaction and dispute, through which people assume and transform their positions regarding nation, government, region, environment, community and themselves; recognizing differences and finding ways to negotiate and transform their condition in contexts of differential power (Li 2000; Porro et al. 2011; Sundberg 2002).

Indigenous and mestizo peasants, merchants, cattlemen, tourism operators, tourists, urban inhabitants, academics, environmentalists, NGOs, government agents, among others, coexist in LR. According to Sundberg (2006), the presence of all these actors makes it possible to consider conservation as a place of interaction between individuals and groups with very different historical backgrounds, cultural nuances and power resources, creating what she calls "conservation encounters." In some cases, those encounters result in dispute and conflict, and in others, empathy and collaboration (Sundberg 2002, 2006). Conservation encounters are specific places of social interaction where discourses and practices reconfigure power relations and subjects' positions and, therefore, identities (Fearon 2009; Sundberg 2006; Vadjunec et al. 2011b).

Power in conservation encounters is the capacity to act within social structures that both allow and restrict human agency. As individuals and groups take part in social relations by mobilizing their identity and other resources, they reshape, transform and reproduce the web of power (Reik et al. 2008). Conservation encounters place our attention on a wider social space considering not only how people react to conservation, but also how social and environmental formations are transformed through conservation (Sundberg 2006). Other concepts such as "public arena" have been used to explain how actors in LR engage in political action (Calleros Rodríguez 2014), but this denotes an institutional setting where conservation is not always relevant.

This study was conducted in LC, an agrarian community ${ }^{5}$ created by presidential decree in 1972, when the government, trying to stop the LR colonization and deforestation, gave away 614,321 hectares of land to 66 Lacandon indigenous people and their families, who were considered the legitimate owners of the rainforest (Calleros Rodríguez 2014; de Vos 2005; O'Brien 1998). The LC decree created deep conflicts over land, because several Tzeltal and Chol communities settled there became illegal occupants when the area was given to the Lacandons (de Vos 2005; Trench 2008a). In the following years, the land rights of some communities were restored, but those that could not demonstrate land ownership acceded to relocation into two new settlements which became, in 1979, sub-communities of the LC: Nueva Palestina, that grouped 822 Tzeltal families coming from 15 villages, and Frontera Corozal, where 474 Chol families from 8 villages were concentrated (de Vos 2005). Today, the LC has five sub-communities: Nahá, Metzabok and LacanjáChansayab inhabited by Lacandon people; Nueva Palestina by Tzeltals; and Frontera Corozal by Chols (Figure 1). The LC has a three-level governance structure, composed by the overall community, the sub-communities and the wards (Calleros Rodríguez 2014). The total number of founding members with land rights as "comuneros" in LC was 1,718 in 2006.

Information was gathered, between 2009 and 2013, in six visits of ten to twelve days each to the LC subcommunities of Frontera Corozal, Nueva Palestina and Lacanjá Chansayab, using ethnographic techniques such as semi-structured interviews and participant observation. In those years, even though most of the agrarian problems related to the demarcation of the LC tract of land had been formally resolved (Ascencio Franco 2008; Calleros Rodríguez 2014), the socio-political situation was somewhat tense. Nearby communities had invaded the lands of LC, members of the LC were also invading MABR's restricted areas, and discontent among peasants without land rights was increasing. Simultaneously, the CONANP was trying to get LC approval to update the MABR management plan (INE 2000), and various government agencies and NGOs were discouraging the extensive cattle farming and slash-and-burn practices for maize cultivation, proposing

\footnotetext{
${ }^{5}$ Comunidades agrarias and ejidos are collective forms of land tenure in Mexico created by the State as part of the postrevolutionary land reform. The former are lands that were historically occupied by indigenous communities and that were recognised or restituted to them by the State, whereas the latter are land grants given by the government to groups of peasants.
} 
schemes such as payment for environmental services, ecotourism and the production of non-timber forest products.

In this article, after describing the social context of the LR and the LC, three ethnographic situations are presented to illustrate identity transformations in LR conservation encounters. The first situation describes how Lacandons, Chols and Tzeltals assume their cultural differences and adopt a position in relation to nonindigenous actors. The second illustrates the way in which Chol and Tzeltal inhabitants assume the role of "rainforest guardians", a tag created and imposed by authorities, and how they negotiate with this component of their identity to obtain benefits from national and international interest in LR preservation. Finally, the third situation shows how a new generation of Chol indigenous peasants, offspring of LC community founding members, detach themselves from their parents' identity and practices to create their own, only to find access to land and economic resources monopolized by both their parents and the MABR.

\section{Context and creation of conservation encounters in MABR}

The conservation movement became relevant in Mexico in the 1990s, and after signing the Rio Earth Summit agreements in 1992 the country assumed some new responsibilities (Lezama 2010). In this decade, $80 \%$ of today's Mexican biosphere reserves were established, and the number of conservation-related NGOs increased (CONANP 2015; Simonian 1999). However, in Mexico, PA decrees do not alter previous land tenure and people can continue to live inside of certain zones of the protected areas. By 2005, 5.7\% of the national rural population lived inside PAs (Bezaury Creel and Gutiérrez Carbonell 2009). Although MABR was created in 1978, it was not until the nineties when conservation started to influence the LR social dynamics (O'Brien 1998). Between 1981 and 1998, other federal protected areas were created $^{6}$, and the area dedicated to conservation in the region reached 421,222 hectares. Some $83.9 \%$ of the PA extension in the LR region is collectively owned by LC members (Legorreta Díaz and Márquez Rosano 2014).

By 2010, LC's total population was 16,783 people, of which 1,011 were Lacandons, 10,588 Tzeltals and 5,184 Chols (Ascencio Franco 2008; Legorreta Díaz and Márquez Rosano 2014). To reinforce LR conservation, besides relocating and concentrating the population, the government established the MABR, comprising more than $50 \%$ of the LC area and other lands of 35 communities legally and illegally settled (INE 2000; Tejeda Cruz 2002, 2009; Trench 2008a). The LC and MABR implementation, which involved the creation of new villages, the relocation of population and restrictions regarding natural resource use, shaped a scenario with many disputes about land ownership and conflicts between different ways of interacting and comprehending the rainforest.

Cattle-ranching is central to the local economy, being the main productive practice in Nueva Palestina and Frontera Corozal, as well as subsistence farming (maize, pepper and beans). Cattle are particularly important in Nueva Palestina, whose economy is closely related to cattle trade in the nearby cities of Palenque and Tenosique (Tejeda Cruz and Márquez Rosano 2006). In Frontera Corozal, and especially in LacanjáChansayab, tourism is an important activity, as the famous Mayan archaeological sites of Yaxchilán and Bonampak are close by, attracting thousands of tourists every year. In these three sub-communities, the mostly illegal harvest and sale of Xate palm (Chameadorea sp.) is an important activity for the poorest families (Buda et al. 2014).

\section{Ethnographic situations}

First situation: rainforest guardians or "we are not kaxlanes"

Chols, Lacandons and Tzeltals that live in LC recognize themselves as different from each other, even though they share the same territory. Chols and Tzeltals believe Lacandons have 'another way of thinking' because of their small populations and the fact that they have lived in the forest for centuries. Even though the

\footnotetext{
${ }^{6}$ The other federal protected areas in the region are: Lacantún Biosphere Reserve, Nahá Biosphere Reserve, Metzabok Biosphere Reserve, Chan-Kin Flora and Fauna Protection Area, Bonampak Natural Monument, Yaxchilan Natural Monument and the Palenque Natural Monument (Figure 1).
} 
Lacandons experimented with livestock around 1970, and sometimes burn their plots to prepare the land for maize cultivation (Trench 2002), Chols and Tzeltals believe Lacandons dislike cattle ranching and do not use fire for agriculture. In their view, the Lacandons have a lot of rainforest because "they occupy the land but don't abuse it" and because"they practice ecotourism" and "are closer to nature." A Tzeltal peasant stated:

Well, in our village [Nueva Palestina], it seems they want to cut down all the trees, do away with the rainforest, but the Lacandons are very different; they have kept it conserved and well-tended, because they don't grow milpas and only use small plots of land and don't work a lot. In Frontera Corozal it's the same as in Palestina. ${ }^{7}$

Lacandons believe Chol and Tzeltal people are indigenous like them but, at the same time, they are different because they remove the forest for maize cultivation and cattle ranching. One Lacandon mentioned that "Tzeltals and Chols think very differently. They have another vision. If they thought like Lacandons, they wouldn't bring in so much cattle farming...We [Lacandons] are the only ethnic group that doesn't raise cattle." For Chols and Tzeltals, Lacandons "hardly work at all", that is, they do not grow maize or breed cattle, since they make a living from ecotourism and receive financing from CONANP and other government agencies. With that money, a Tzeltal peasant explained, Lacandons finance conservation projects in their communities, but also support themselves:

We don't know, but we have heard, that they (the Lacandons) get support... for not cutting down the rainforest. We believe that, because how can a human being live without eating, without food? They have food, they have everything, and they even have cars, where did they get it? We think they get support... Chols work; they have cattle and milpas, but the Lacandons don't have milpas or cattle ranches or anything. They get by because of the money, that's how they survive... because without money you can't buy anything. They buy their maize, they buy and buy whatever they want. They live easy lives, they come here to visit, to buy, but what about us? We must work very hard... ${ }^{9}$

For Frontera Corozal and Nueva Palestina inhabitants, the Lacandons' work is keeping the forest for tourists and, in fact, the Lacandon people explain their role similarly. One Lacandon peasant told me that "the rainforest brings us tourists; they come to see the nature and don't want to see cattle ranches. They want to see animals, the toucan, not to see corrals. If there's no more jungle, tourists won't come. I wish the other indigenous people understood, we live off tourism, all of us live from tourism..." ${ }^{10}$ Chols and Tzeltals know that the big extensions of forest that Lacandons own grant them more legitimacy in the eyes of the government, because the rainforest is currently a valuable resource treasured by powerful agents such as NGOs, academics, environmentalists, public officials and government agencies. This allows the Lacandons to establish close links with local and federal authorities who, at the same time, re-create and reinforce the dominant image of Lacandons as nature stewards. Some employees of government offices, such as CONANP and the Federal Bureau of Environmental Protection (PROFEPA), believe Lacandons know how to take care of the forest because they possess valuable ancestral knowledge (Barrera et al. 1977; Contreras Cortés et al. 2013), while Tzeltals and Chols, who colonized the region between 1950 and 1970, "have to reconstruct their relationship with the ecosystem" because they come from other regions and don't know how to implement adequate productive practices in the rainforest.

The Lacandon people who live the old way, on their scattered parcels of land... and obviously, from an environmental point of view, they don't affect the jungle because they are not aggressive.

\footnotetext{
${ }^{7}$ Tzeltal peasant. Nueva Palestina, October 2009.

${ }^{8}$ Lacandon peasant. Lacanjá Chansayab, September 2010.

${ }^{9}$ Tzeltal peasant. Nueva Palestina, October 2010.

${ }^{10}$ Lacandon peasant. Lacanjá Chansayab, September 2010.
} 
Compared with the Tzeltals, who are cattle ranchers, that's another story; two completely different worlds... Besides, the birth rate of Tzeltals is nothing like the Lacandons. Lacandons have two kids per family and that's it, and they [Tzeltals] are like rabbits, they have all the children they can... ${ }^{11}$

Through these narratives, it is possible to observe the colonial legacy that remains in conservation practices in Mexico (Adams 2003). Based on a clear distinction between natural and social issues, a hierarchy of inhabitants is produced from a romantic interpretation of nature as a harmonious space perturbed by human presence and by situating some ethnic groups closer to nature than others. A clear example of this is the Agreement on the Rights of Chol and Tzeltal Groups in the Lacandon Zone (Convenio sobre los Derechos de Grupos Choles y Tzeltales en la Zona Lacandona), signed on March 30, 1977, between representatives of the three ethnic groups, the Agrarian Reform Ministry (SRA) and the state government. This agreement, besides settling the landless Chol and Tzeltal people in the LC, established that Lacandons would hold the ruling power since a Lacandon member must always occupy the presidency of the LC Council, the preeminent government organ of the LC (Calleros Rodríguez 2014). The agreement gave Lacandons great power in defining the LC agenda, guiding discussion and negotiation, and influencing final agreements (Tejeda Cruz 2009). This document explains that this measure was adopted to defend the interests of Lacandons as a minority but, in fact, contributed to creating a long-lasting alliance between federal and local authorities and the Lacandon people. This alliance facilitated government negotiations with the LC for decades. A high officer of PROFEPA with much experience working in the area explained that "it is very easy, in terms of conservation and the environment, to come to agreements and negotiate with the Lacandons, they have their style and their ways, but it is much easier than with Palestinos (Tzeltals) who are very difficult, or with Chols." ${ }^{12}$

Tzeltals wear western clothes with boots and cowboy hats and are less stereotypically indigenous than Lacandons, who still look primitive walking through the jungle with long white tunics and long hair (Trench 2005; Villalobos Cavazos 2012). Besides, Nueva Palestina lacks major tourist attractions such as Bonampak or Yaxchilán, and is not an exotic place. The lack of ecological and archaeological interest in their lands gives Nueva Palestina inhabitants less cultural and material resources to insert themselves into conservation. They have a clear disadvantage compared with Lacandons, who frequently appear, with their exotic aura, in TV commercials and ads promoting the state of Chiapas, using their identity in strategic ways (Trench 2005).

Some studies report the existence of substantive ecological knowledge between Palestinos (Paladino 2005) but they are known basically as cattlemen and criticized for their preference for extensive cattle ranching, a productive practice strongly rejected by environmentalists because of its low productivity and the deforestation it produces. One of the public officials interviewed explained that "every Tzeltal wants to be a cattle rancher." He attributes this desire to ignorance or lack of environmental awareness because, in his opinion, Tzeltals only want "a big truck and lots of land to raise cows." Even when clear data regarding the magnitude of the deforestation that each ethnic group has caused at the MABR are not available, Tzeltals are seen as the "major destroyers of the jungle" because of their inclination towards cattle breeding and having many children (de Vos 2010: 228). Moreover, it is said they like money and have a more aggressive disposition, which sometimes leads to violent acts ${ }^{13}$; as a PROFEPA official told me "killing each other is an Olympic sport to them" (see Calleros Rodríguez 2014; de Vos 2010).

Chols, on the contrary, are comprehended to be more reasonable. In general, people say they think more clearly and produce less deforestation in their lands (Ascencio Franco 2008; de Vos 2010).

Chol people think more, they analyse, they are more analytical, you know? Anybody can tell you that, any outsider will tell you that Chols analyse things more; they analyse the problem

\footnotetext{
${ }^{11}$ PROFEPA official. Tuxtla Gutierrez, 2010)

12 PROFEPA official. Tuxtla Gutierrez, 2011.

${ }^{13}$ The inhabitants of Nueva Palestina are accused of committing violent acts like those occurring at the village of Viejo Velasco Suárez in 2006, where 4 people died (Calleros Rodríguez 2014; de Vos 2010).
} 
well, in detail and they take their time. In contrast, the Tzeltals are quick, and they are quick to get angry, but they are easier to convince. ${ }^{14}$

Although the Lacandons have a privileged position within the LC, interviewees from the three ethnic groups considered the relationships between them to be good and feel they can make agreements and choices together, even though this is not always easy. Chols, Lacandons and Tzeltals conceive and view themselves as different, but they act together in response to perceived outside threats. LC inhabitants distinguish clearly between the LR indigenous people and white people, kaxlanes in Maya, be they environmentalists, academics, government officials or entrepreneurs with an interest in their lands and resources. For example, when describing some LC land invasion conflicts that occurred between 1980 and 1990, one interviewee remembered the train of thought he had during the negotiation with one of the invading indigenous groups from a neighboring village:

...we see each other as enemies on both sides; you said you were going to kill us... but if you kill us, we will kill you, too. Look what we say to each other, but we are of the same blood, we are not like the kaxlanes, that have studies, professions, they can live in cities, but even if we fight for our children, to send them to school, sometimes we can't because we lack the resources. The only place we can live is in our mother land because there's nothing else to fill our stomachs. Because, if we don't work, what are we going to live on? ${ }^{15}$

The inhabitants of the LC define themselves as indigenous and different from kaxlanes but, paradoxically they have accepted an identity imposed by kaxlanes, who demarcated the LR as a conservation area and named its inhabitants "rainforest guardians." In 1975, when Chol and Tzeltal people accepted integration into the $\mathrm{LC}$, they also agreed to prevent rainforest destruction and received from the authorities an ID card that literally named them "Guardians of the Lacandon Community" (de Vos 2005; Leyva Solano and Ascencio Franco 2002; Paladino 2005). A peasant in Nueva Palestina told me that "they used to call it a national park...they called it a reserve because it was useful for the future, the reserve was really useful... and they told us that the government put us here as care-takers, as guardians. That's what they called us..."16

While Lacandons take advantage of their image as people who lives in balance with the rainforest (Trench 2005), Nueva Palestina and Frontera Corozal inhabitants' contest dominant representations arguing that they take care of the rainforest as much as Lancandons do. They are also "rainforest guardians" because they live in the LC, they know their territory very well and they are comuneros. "But", a Tzeltal man asked:

what would happen if people, even though the government says we are going to take care of it, what if the people say we'll cut down the rainforest? The government would never know. Because they never come to check on it. That's what you need to know. They never come and they never take care of it. So, who really takes care of it? The comuneros. ${ }^{17}$

Second situation: We take care of the forest, but we can sell it too.

Frontera Corozal and Nueva Palestina comuneros are constantly interacting with conservation authorities, especially CONANP. The CONANP's offices for the LR region are in the Lacandon village of San Javier, a few kilometers from Nueva Palestina and Frontera Corozal. Officials and technical personnel from CONANP work some days of the week at San Javier and other days at offices in Tuxtla Gutierrez, the capital of the state. According to testimonies, there are around 30 park rangers for MABR, usually inhabitants from the LC and nearby regions of Las Cañadas and Miramar, as well as 9 technicians hired for the offices in San

14 Chol peasant. Frontera Corozal, September 2013.

15 Tzeltal peasant. Nueva Palestina. September 2013.

16 Tzeltal peasant. Nueva Palestina. September 2010.

${ }^{17}$ Tzeltal peasant. Nueva Palestina. May 2009. 
Javier. These personnel must watch and monitor an area of over 300,000 hectares; therefore, while the presence of CONANP in the area is constant, it is still limited.

Although the CONANP is formally responsible for rainforest conservation, the Chol and Tzeltal people argue they are, together with the Lacandons, the true rainforest guardians rather than the environmental authorities or NGOs. The comuneros say CONANP personnel almost never visit their villages, that they do not go into the rainforest, and that it is them, the locals, who take care of it and solve emergencies such as forest fires. A peasant in Nueva Palestina said that:

If you want to know about how to take care of the rainforest, how to defend it, we know more. Because we can do it. If we have to fight a fire, we really fight it. The government doesn't even come anymore, we go into the rainforest and sometimes we get lost, but we manage, I tell you. We don't need planes, or other things. Because we have experience in how to put out the fire, how to bring it down and end it, until it's out. ${ }^{18}$

From the comuneros point of view, the rainforest continues to exist because of them and, although they consider it important to take care of the forest to preserve the water, timber and other resources and ecological services, they explain that the creation of MABR forced them to give some of their land to conservation, and this is onerous as they cannot grow maize or pasture in a large portion of the LC area. The tension that comuneros experience over maintaining their access to land and the need to follow conservation policies (Trench 2008a) results in a persistent interest of Chols and Tzeltals in obtaining concrete benefits in exchange for land in conservation. The expected benefit is usually money, or "recursos" (resources) as they call it. The demand for resources increases and is legitimated by the widely extended impression among indigenous people that there is a great amount of money available to finance MABR, money that, in their opinion, never reaches their communities.

Currently MABR operates with limited financial resources. Only around US $\$ 1,900,000$ per year is invested in all federal reserves in the $\mathrm{LR}^{19}$ (Trench 2014 pers. comm.). However, during the 1990s, government agencies and NGOs invested large sums of money in regional development and conservation. The NGO Conservation International (CI) started its work in the area at the end of the 1980s. Through two "debt for nature swap" agreements with the Mexican Government, one in 1991, and another in 1995, CI obtained over US $\$ 2,600,000$ for LR conservation. Later, in 1995, CI got a US\$10,000,000 donation from the Mexican business consortium Grupo Pulsar. Local and federal government also channeled money to the LR. Between 1991 and 1994, the Program for Conservation and Development of the Lacandon Rainforest (PCDSLPRODERS) operated a loan from the World Bank for 30 million dollars, while the Chiapas government and the European Community reached an agreement for financing and promoting sustainable development, providing US $\$ 35,000,000$ implemented through the Project for Integrated Social and Sustainable Development at the Lacandon Rainforest (PRODESIS) (de Vos 2010; O'Brien 1998; Muench 2008). Between 1995 and 1997, the Environment, Natural Resources and Fishery Ministry (SEMARNAP) and the Social Development Ministry (SEDESOL) increased their funding to LR to address the demands of the population and avoid adhesion to the Zapatista Army for National Liberation (EZLN) when armed conflict broke out in 1994 (Tejeda Cruz 2009). Although this review of financing for LR conservation in recent decades is not exhaustive, the data shows that the region has truly received an important sum of money (Ervine 2011). The results of those investments, however, have been questioned, as they are not always visible to LC inhabitants because a large amount of that money is invested in salaries and operational costs. Just for the PRODESIS project, about $15 \%$ of the total financing or almost US\$ 5,600,000, were used to pay salaries (de Vos 2010). Therefore, comuneros, especially Chols and Tzeltals, frequently claim that the money never reaches communities:

\footnotetext{
${ }^{18}$ Tzeltal peasant. Nueva Palestina, May 2009.

${ }^{19}$ This sum includes the operating cost plus money assigned for the operation of subsidy programs, such as the Conservation Program for Sustainable Development (PROCODES) and Temporary Job Program (PET) implemented by CONANP.
} 
The United States government spends millions and millions of dollars specifically for the reserve, but that money never reaches us, never reaches the hands of the Lacandon community. Although we are members of the community, not a cent comes to our hands. Only the director of the reserve, the personnel and the people they send, the director of the reserve's lackeys are benefitted. They have luxury cars, the latest model. ${ }^{20}$

Limited in their use of the land and knowing of the existence of rainforest conservation funds, comuneros constantly try to access those benefits, and therefore negotiate with the most valuable resource they possess, both material and symbolic, the rainforest itself. Those efforts have not been fruitless, during the last decade, comuneros found two great opportunities to be compensated for their contribution to conservation. The first was a result of the state government's interest in resolving the area's complex agrarian problems, which entailed the expropriation of the land to the LC and to the Environment and Natural Resources Ministry (SEMARNAT). The second was through implementation of a pilot program for Reducing Emissions from Deforestation and Forest Degradation (REDD+) in Chiapas.

Between 2003 and 2006, the SRA promoted the Program for the Integral Care for the Lacandon Community Area and the Montes Azules Reserve with the purpose of regularizing land ownership through relocation, expropriation and vacating land (Ascencio Franco 2008). Part of the LC land was occupied by various illegal villages, 23 of them were regularized by the government by expropriating the lands to the LC. In this way, the illegal communities became ejidos and LC comuneros, who lost part of their lands, received US\$ 33,200,000 as compensation (Ascencio Franco 2008; Trench 2008b).

The comuneros from Nueva Palestina and Frontera Corozal decided to divide the money obtained from the compensation in equal parts and, according to interviews, each one received around US\$23,000, a large amount if we consider that in the municipality of Ocosingo, where the LC is located, $32 \%$ of the population does not receive any income, and $41 \%$ receive less than US\$4 per day (Ascencio Franco 2008). In one of the ceremonies to hand payments to the LC comuneros, the head officer of the SRA warned them, maybe out of foresight, and at the same time distancing himself from what could happen later: "You are adults and know how to distribute this resource to set up other activities. Let's hope this money becomes an opportunity for you to carry out other economically fruitful projects" (Mariscal 2006). In an assembly of Nueva Palestina, authorities, recommended the same thing, encouraging peasants to use the money in a productive way and avoid spending it "at the cantina." Indeed, the money the comuneros received was an unparalleled opportunity to promote productive projects or accomplish some personal or collective goal. For the comuneros, this was an extraordinary situation, a huge privilege when compared with other communities of the region and the country.

Many people acknowledged that the amount of money they received was unprecedented and they did not very well know how to use it; some of them managed to organize and finance a joint project, but it seems there was never an intention to use it for a long term or collective project. Each comunero decided how to spend the money he received, according to his own expectations, capabilities and resources. For some, the compensation allowed them to buy a house, cattle or a car and secure some patrimony. For others, the benefits were more ephemeral: some were scammed into buying illegal cars from the United States, others bought food or presents. Maybe those resources could have been administrated in a different manner, but nobody was prepared, and the warnings issued by authorities were obviously not enough to construct new abilities and visions. A Tzeltal comunero said that "nobody had ever even dreamed of money like that.... Nobody had ever seen that amount before... and it's all gone...each one did whatever they liked with the money..." ${ }^{21} \mathrm{~A}$ son of a comunero shared his opinion stated that "with the money we received as compensation, you could say some of us did well, others wasted it. Many didn't know how to do business, they just spent it. My father gave me some and I bought a house, he bought a truck to work, and we made a corral, he didn't waste it."22

\footnotetext{
${ }^{20}$ Tzeltal peasant. Nueva Palestina. September 2009.

${ }^{21}$ Tzeltal Comunero. Nueva Palestina. May 2009.

${ }^{22}$ Son of a comunero. Nueva Palestina. June 2010.
} 
A few years later, when the pilot program REDD+ was implemented, the Lacandon, Tzeltal and Chol comuneros form LC again received money, merely because they were the legitimate owners of the rainforest. With the supposed intention of generating capacities and experience to operate REDD + , the governor of the state of Chiapas, Juan Sabines Guerrero (2006-2012), launched a pilot program for the LR in 2011 (Fades 2014). This program was widely criticized by local NGOs, academics and some federal agencies, because it did not respect the discussion and implementation processes of the REDD+ program in the rest of the country, and it did not become a real carbon credit market. There was no quantification of the number of carbon tons offset nor those being offered to the market, the plots included in the program were not delimited, nor was there any type of monitoring regarding the permanence of forest cover (Fades 2014).

The pilot program REDD+ operated in the LR from 2010 to 2013, after the Pact for the Respect and Conservation of Mother Earth was signed between the state government and the LC. In this pact, the comuneros committed to preserve the forest on their lands in exchange for US\$100 a month (Mendoza 2012). Due to the lack of clear obligations for comuneros, the program became a subsidy for conservation, yet despite the criticism it received from NGOs and academics, and the lack of specific results, the comuneros of Nueva Palestina and Frontera Corozal considered the pilot REDD+ project as a fair compensation for their conservation efforts. A Chol peasant said:

I think it's good, when you have jungle, it's a shame to burn it; it's better to leave it there, it's pretty, there are birds, animals, this REDD+ norm proposed by the state government, it's good for taking care of the rainforest. We need the federal government to contribute its share of the money, too. ${ }^{23}$

I don't think the REDD+ program is bad, I think it's fair to the people that take care of the rainforest. They say it makes people lazy, but it is because of people that the jungle exists... When the REDD+ thing happened, people took care, they didn't burn or hunt, people paid attention... ${ }^{24}$

The stories about negotiations between community members and the state government to establish the amount of the REDD+ monthly payment, clearly shows that comuneros are aware of the political value of the ecosystem they possess. This gives them great bargaining power, and they use this power every time they can to increase their retributions as "rainforest guardians." One interviewee in Frontera Corozal said that the comuneros knew before a meeting with officers of the Environment and Natural History Ministry (SEMAHN) of Chiapas that there was US\$4,200,000 to be used for the LR through REDD+. At the assembly, the LC decided to accept the program thinking they would receive all the money in one payment, or "in a flash" as they said in their testimonies. When they found out, from the governor himself, that the initial proposal was for payments of around US\$77 per month for each comunero over the course of two or three years, they became very upset and asked for more money. As a peasant from Nueva Palestina explained:

The Governor brought a proposal of 1,000 pesos [US\$50] per month. The people from Frontera (Corozal) asked for 15 or 20 thousand pesos and didn't accept. Those from Palestina also started asking, they wanted 8 thousand pesos. Finally, the governor accepted the proposal of 2,000 [US\$100] and first Nueva Palestina and Lacanjá accepted, and Frontera Corozal was left out... ${ }^{25}$

Another opined:

${ }^{23}$ Chol peasant. Frontera Corozal. September 2013.

${ }^{24}$ Chol peasant. Frontera Corozal. September 2013.

25 Tzeltal peasant. Nueva Palestina. June 2011. 
I think 2,000 [US\$100] pesos are too little to not cut down the rainforest, I think 10,000 pesos per month [US\$500] would be enough. The Frontera people wanted 10,000 [pesos], but if they say the reserve is ours, then they should support us. 10,000 pesos would be fair... ${ }^{26}$

Finally, comuneros managed to double the amount of the initial payment proposed by the authorities and obtain a commitment to seek federal funding and maintain the payments after the assigned budget ran out. Nevertheless, the project was suspended in July 2013, because the incoming government of Manuel Velasco Coello (2012-2018) considered it a great failure (López 2013). Currently, some Nueva Palestina and Frontera Corozal comuneros receive payments for "the environmental services they perform as nature guardians" (Instituto de Comunicación Social 2014) through programs operated by the National Forestry Commission (CONAFOR) since 2010.

\section{Third situation: We think differently, so we can conserve the rainforest}

In Nueva Palestina there are 805 comuneros, and 601 in Frontera Corozal. However, there are around 2,500 adult males in Nueva Palestina and 1,500 in Frontera Corozal with no land. They are hijos de comuneros or sons of the original comuneros who founded both communities. The lack of agrarian rights does not allow the sons of comuneros to obtain benefits from government subsidies, which are often linked to land rights. Although they are a rather large and important population segment, the sons of comuneros are marginalized and have become invisible to authorities and state agencies for whom the land holders are the preferred representatives. Politically, they are also at a disadvantage. Although they can attend assemblies, they do not have any influence on decisions made in their communities, nor in the LC general assembly (Figueroa and Durand 2015).

Not owning land prevents the sons of comuneros from using the rainforest as a powerful resource in the way their parents do, thus, they have developed other strategies to deal with conservation. One such strategy is participating in projects run by authorities and academics. These projects include agricultural commodities (organic coffee, pepper and rubber) and activities such as sustainable production of non-timber species, such as Xate palm, handicrafts, semi-intensive cattle farming and, most importantly, ecotourism.

Ecotourism is currently considered a potential solution to integrate environmental conservation with local development in Mexico (Durand 2014). It is assumed that the implementation of successful ecotourism projects (ones that become profitable for the communities) can compensate conservation costs for local people and promote interest in conservation itself. For example, during the opening of the World Summit for Adventure Tourism that took place in San Cristobal de Las Casas, Chiapas, in 2011, the former Mexican president, Felipe Calderon said:

We know how to find options for employment and income for those who own towns, land, forests, jungles and deserts, lakes and ponds, through adventure tourism. I think we can find a just way to correct the terrible inequality in our country and the world (Herrera 2011).

In the LR, many comuneros and their offspring have started businesses related to ecotourism. Local people strive to attract customers and offer, besides transportation, lodging and meals, new services such as cultural fairs, food festivals, spas, massages, guided tours, hiking, camping, etc. The promotion of tourism businesses is already a common practice among many indigenous LR communities, and the sons of the comuneros see ecotourism as an opportunity to join conservation projects and obtain access to land and other resources.

Due to the government's interest in preserving the remaining vegetation, the sons of comuneros are aware that continuing with their parents' productive practices, maize cultivation and extensive cattle ranching, would eliminate any possibility of them gaining access to land and resources, to join the conservation schemes,

\footnotetext{
${ }^{26}$ Tzeltal peasant. Nueva Palestina. June 2011.
} 
they make great efforts to clarify that they are different and think differently. Although the sons of comuneros want to live in the rainforest and use its resources, they assert, perhaps only as a rhetorical strategy, that they can do it well, working and preserving the rainforest at the same time, just as the government and NGOs propose. A son of a comunero declared that:

We believe we already think very differently from our parents, we are thinking about eco-tourism projects, walking trails, wildlife management, creating a forest management unit, as a group, maybe that way... but we should have a document that says that we are owners, too, that we are owners of the Lacandon Rainforest. ${ }^{27}$

Another, said:

...we have a different way of thinking and working the land. I mean, I won't necessarily cut it down, you know? I can also conserve, plant trees or whatever like the xate palm, and I can live off that. ${ }^{28}$

Although some comuneros share the "resources" obtained from the government and other institutions with their offspring, this is not common and many sons of comuneros believe that their parents receive money without working, creating a paternalistic relationship with the government. Additionally, both at Nueva Palestina and Frontera Corozal, there are sons of comuneros with college degrees, who are now biologists or lawyers. They can read and write Spanish fluently, they have computer skills, use social media and have relationships outside communities. They think that their parents are not qualified to make good use of the money they receive because they obtain it without effort. "The problem", one told me,

is that our community is in disarray because of this, because people are used to only receive [money]. In the beginning, they received compensations for timber exploitation, and for profits from gum trees, the Xate palm and for opening the border highway, and the famous PROCAMPO, the permanent land compensation, the REDD $+\ldots$ lots of things, that have made us addicted to money in a bad way. ${ }^{29}$

Some sons of comuneros explain that, unlike their fathers, they "want to make things right", showing great interest in government and certain NGO plans to make them natural capital entrepreneurs. This is exactly the case of the group of offspring of comuneros who formed a bio-archaeological tourism organization, at Frontera Corozal in 2007. This is a cooperative formed by 12 men and 2 women, young Chols form Frontera Corozal who, in the words of one of the founders, Ramiro ${ }^{30}$, saw an "opportunity niche" to start a different business. He explains, referring to tourists that came to Frontera Corozal to visit the Yaxchilán ruins, that "they needed information but also wanted to interact with our community, but nobody would initiate this interaction." Thus, they thought it would be a good idea to create a group of guides that could offer services to visitors with sufficient information about the archaeological ruins and life in Frontera Corozal, since they had a captive market in their community. However, to avoid making the same mistake made by comuneros, who never trained to offer ecotourism services, they thought that the first thing they should do was to prepare themselves. They took several classes that after almost a year allowed them to become tourist guides certified by the federal Tourism Ministry (ST) and started their work. As Ramiro explained: "you have a product, now sell it."

\footnotetext{
${ }^{27}$ Son of a comunero. Frontera Corozal. September 2013.

${ }^{28}$ Son of a comunero, Nueva Palestina. October 2009.

${ }^{29}$ Son of a comunero. Frontera Corozal. September 2013.

${ }^{30}$ The name is fictitious, to preserve interviewee privacy.
} 
Ramiro's language is full of business and marketing terms. He talks about resources, investment, business plans, prices, competition, costs, customers, quality and services, among other terms not heard very often in interviews with the old comuneros. For these offspring of comuneros, conservation encounters are driven by a neoliberal conservation discourse, according to which it is necessary to make conservation profitable to be effective (Durand 2014). They think of themselves as micro-entrepreneurs that sell "all the services within the community and products that can be generated with all the attractions we have."

However, the understanding of their productive activities as a business does not detract from their image of themselves as indigenous Chol people. On the contrary, the Chol identity adds interest to the products and services they offer, because it makes their services different from what Lacandon and Tzeltal peasants offer. Reclaiming what it means to be a Chol is currently a concern of young Frontera Corozal sons of comuneros, but it is also a new product to be sold. Ramiro explains that one of the products their organization sells is an experience package called 'Chol life' in which tourists, after visiting Yaxchilán, are taken to peasant houses in the community to see how people live, watch their rituals, buy handicrafts, etc. This also occurs in other local enterprises, such as 'Hotel Nueva Alianza', operated by sons of comuneros, where cotton sheets are embroidered with traditional Chol designs, and restaurants in the village offering traditional Chol meals. For some interviewees, this kind of initiative constitutes a 'new model of Chol tourism' implemented by young Chol people who have created a new identity in conservation encounters.

\section{Conclusion}

Conservation encounters in MABR bring together disparate actors with different cultural, economic and political resources to deal with the discourses and actions of conservation institutions. In this process, identities, as part of subject positions, are recreated and "come into being in and through the action of conservation encounters" (Sundberg 2006: 242). In the LC, comuneros use their 'rainforest guardians' title in unexpected ways, as an important instrument to negotiate and achieve their goals. Over the years, LC comuneros have managed to accumulate a significant amount of political capital because, in 1978, when MABR was established, they inhabited a rainforest that few people knew about. Today, they preserve the last, most important, and most endangered remnant of tropical rainforest in North America and Mexico. Hence, some identity features that may, at times, place comuneros in a subordinate position, are useful, in other moments and settings, to strengthen their political influence over other actors.

Chol, Tzeltal and Lacandon comuneros, agree to be "rainforest guardians", assimilating an identity feature created by powerful agents, such as the government and NGOs. However, Chols and Tzeltals are not as successful as the Lacandons at representing themselves as genuine indigenous people who really care for the forest, because identity is created and recreated through interactions, in this case, particularly between local people and conservationists (Campbell 2005; Haenn 2016). Outside institutions like CONANP, PROFEPA and national and international NGOs, contribute to shaping identity positions and reinforcing the Lacandons' privileged identity, allowing them to have more influence in the decision-making process in MABR than Choles and Tzeltals (Trench 2002). However, this circumstance is not accepted without resistance. For example, in 2014, Chol and Tzeltal comuneros changed the LC statutes and elected, for the first time in more than 50 years, a Tzeltal comunero as president of the LC Council. The Lacandons protested and demanded help from the state and federal authorities to revert the LC Council decision, but they did not succeed (Mariscal 2014). Internal conflicts between the Lacandons and the numerical superiority of Chol and Tzeltal people who represent more than $90 \%$ of LC inhabitants and almost $80 \%$ of the comuneros, create new spaces for the political recognition of the latter, despite Lacandons' identity as exemplar conservationists. However, other identity traits are less contested. Chols, Tzeltals and Lacandons describe themselves as indigenous and moreover as LC comuneros and different from kaxlanes, allowing them to act together and join forces to face external actors or threats, as happened when the LC negotiated REDD+ payments.

For those who are not comuneros, like the group of sons of comuneros who works as ecotourism guides in Frontera Corozal, the option to deal with conservation is to differentiate themselves from their parents by creating a new identity, one linked to more modern and accepted practices such as ecotourism (Perrault 2001). Ecotourism, as one of the interactions derived from conservation encounters, plays an important role in 
transforming not only local identities but also indigenous communities' livelihoods. Ecotourism without a doubt represents new income opportunities for LA inhabitants but it is not a panacea and carries with it problems such as the concentration of benefits, scarce participation of women, and the abandonment of traditional productive practices (Trench 2002; Hernández Cruz et al. 2005). Today, as Trench (2002) explained, the dominant conservation discourse in MABR, which includes ecotourism and payments for environmental services as some alternative productive activities, creates subjects, identities and lifestyles that are considered more suitable for the rainforest than others.

Although the LC inhabitants gained power by adopting a conservationist posture, Chols and Tzeltals have also become more susceptible to criticism because their productive practices are not always perceived as ecologically appropriate or sustainable by others. Some suggest that non-Lacandon comuneros only simulate a "green" façade to take advantage of the conservation context (Trench 2008a; Vadjunec et al. 2011a), and that the same could be said about the sons of comuneros and their interest in government proposals. Though this may be true in certain cases, it must be understood as a by-product of the ambivalent relationship that inhabitants of the LC establish with conservation, which stems from the very history of LR conservation. For Chol and Tzeltal comuneros and their offspring, conservation is a practice imposed by others, a practice that responds to others' interests and that has reduced their control over the territory and its resources (de Vos 2005; Paladino 2005; Tejeda Cruz 2009).

Governmental, NGO, and academic discourses frequently focus on biodiversity preservation and ecosystem integrity and downplay the importance of maintaining cultural diversity and indigenous communities' land rights, which are constantly being sought by the LC (Bolaños 2011; Calleros Rodríguez 2014). However, at the same time, the existence of MABR represents, for some peasants, an opportunity to gain access to institutional and financial resources. In this context, identity should not be understood as a stable and coherent feature of groups and individuals, but as a complex and sometimes contradictory construction with flexible fringes, that takes different forms as peasants fight to reconcile their personal desires with biodiversity conservation (Braubaker and Cooper 2000; Haenn 2016; Vadjunec et al. 2011b). Identity in the LR, as in other regions shaped by conservation such as the Amazon (Brazil, Ecuador), the Petén (Guatemala) or Calakmul (Campeche, Mexico) is a tool of political struggle and may, at times, be strategically mobilized to achieve specific goals and to challenge dominant paradigms and propose better alternatives for local people's aspirations (Li 2000; Navarro Olmedo et al. 2015; Perrault 2001; Sundberg 2004, 2006; Vadjunec 2011b). Nevertheless, it is important to emphasize as Haenn (2016) did, that conservation actors like government officials, peasants or NGO employees are not uniform groups. Porous identity boundaries between those actors can exist and frontiers can be crossed to gain power or reinforce power hierarchies (Haenn 2016). The LR is a setting where huge cultural, political and economic differences will always be present; hence, an analysis of the relationship between identity and conservation is essential to dealing with the environmental issues in the area. Such an analysis reveals both the complexity of meanings associated with the rainforest and the unequal relationships and ongoing negotiations between the diverse actors who confront, resist and cooperate when inevitably gathered in conservation encounters (Sundberg 2006; Vadjunec et al. 2011a).

\section{References}

Adams, W.M. 2003. Nature and the colonial mind. In Adams, W.M. and M. Mulligan (eds.) Decolonizing nature: strategies for conservation in a post-colonial era. London: Earthscan.

Ascencio Franco, G. 2004. Milpa y ganadería en Ocosingo. In Viquiera J.P. and M.H. Ruz, (eds.) Chiapas. Los rumbos de otra historia. México: UNAM-CIESAS.

Ascencio Franco, G. 2008. Regularización de la propiedad en la Selva Lacandona: cuento de nunca acabar. Tuxtla Gutierrez: Universidad de Ciencias y Artes de Chiapas.

Barrera, A., A. Gómez Pompa and C. Vázquez Yanes. 1977. El manejo de las selvas mayas: sus implicaciones silvícolas y agrícolas. Biótica 2(2): 47-61.

Benjamin, T. 1989. A rich land. A poor people. Politics and society in modern Chiapas. Albuquerque: University of New Mexico Press. 
Bezaury Creel, J. and Gutiérrez Carbonel, D. 2009. Áreas naturales protegidas y desarrollo social en México. In CONABIO (ed.) Capital natural de México Vol. II Estado de Conservación y tendencias de cambio. México: CONABIO.

Bolaños, O. 2011. Redefining identities, redefining landscapes: indigenous identity and land rights struggles in the Brazilian Amazon. Journal of Cultural Geography 28(1): 45-72.

Braubaker, R. and F. Cooper. 2000. Beyond "identity". Theory and Society 29(1): 1-47.

Brosius, P. 1999. Analyses and interventions: anthropological engagements with the environment. Current Anthropology 40(3): 277-309.

Buda, G., T. Trench and L. Durand. 2014. El aprovechamiento de la palma camedor en la Selva Lacandona, Chiapas, México. ¿Conservación con desarrollo? Estudios Sociales XXII (44): 200-223.

Burguete Cal y Mayor, A. 2013. Etnoterritorios: la dimension cultural de la apropiación del espacio en regiones indígenas. In CONABIO (ed.). La biodiversidad en Chiapas: estudio de Estado. México: CONABIO, Gobierno del Estado de Chiapas. Pp. 97-107.

Calleros Rodríguez, H. 2014. Land, conflict, and political process: the case of the Lancandon Community, Chiapas, Mexico (1972-2012). The Journal of Peasant Studies 41(1): 127-155.

Campbell, L. and A. Vainio-Mattila. 2003. Participatory development and community-based conservation: opportunities missed for lessons learned? Human Ecology 31(3): 417-437.

Castellanos Navarrete, A. and K. Jansen. 2015. Oil palm expansion without enclosure: smallholders and environmental narratives. Journal of Peasant Studies 42(3-4): 791-816.

Carabias, J. 2009. Los niños en la Lacandona. Reforma. 5 Mar.

CONANP. 2015. Reservas de la Biosfera. [accessed February 18, 2015]. http://www.conanp.gob.mx/que hacemos/reservas biosfera.php

Contreras Cortés, L.E.U., L.C. Barrera, M.A. Fernández and R.M. Mariaca Méndez. 2013. Manejo de los agroecosistemas en la Comunidad Lacandona de Nahá, Chiapas. Etnobiología 11(3): 34-44.

De Vos, J. 2005. Una tierra para sembrar sueños. México: Fondo de Cultura Económica and CIESAS.

De Vos, J. 2010. Camino del Mayab. Cinco incursiones en el pasado de Chiapas. México: CIESAS.

Durand, L. 2014. ¿Todos Ganan? Neoliberalismo, naturaleza y conservación en México. Sociológica 29(82): 183-223.

Durand, L., F. Figueroa and T. Trench. 2014. Inclusion and exclusion in participation strategies in the Montes Azules Biosphere Reserve, Chiapas, Mexico. Conservation and Society 12(2): 175-189.

Ervine, K. 2011. Conservation and conflict: the intensification of property rights disputes under market-based conservation in Chiapas, México. Journal of Political Ecology 18: 66-80.

Escobar, A. 1998. Whose knowledge, whose nature? biodiversity, conservation, and the political ecology of social movements. Journal of Political Ecology 5(1): 53-82

Fades, I. 2014. La despolitización de la ecología. Un análisis del proceso REDD+: México y Chiapas. Masters dissertation. Oslo: University of Oslo.

Fearon, J.D. 1999. What is identity (As we now use the Word?). [accessed October 20, 2014]. https://web.stanford.edu/group/fearon-research/cgi-bin/wordpress/wp-content/uploads/2013/10/Whatis-Identity-as-we-now-use-the-word-.pdf

Figueroa, F. and L. Durand. 2015. Poder, élites locales y gobernanza ambiental. El caso de los hijos de comuneros en la Reserva de la Biosfera Montes Azules. In Brenner, L. and R. Rosales (eds.) Geografía de la gobernanza. Dinámicas multiescalares de los procesos económicos-ambientales. México: Siglo XXI, UAM Iztapalapa. Pp. 233-251.

García Frapolli E., G. Ramos Fernández, E. Galicia and A. Serrano. 2009. The complex reality of biodiversity conservation through Natural Protected Area policy: three cases from the Yucatan Peninsula, Mexico. Land Use Policy 26: 715-722.

Haenn, N. 2016. The middle-class conservationist: social dramas, blurred identity boundaries, and their environmental consequences in Mexican conservation. Current Anthropologist 57(2): 197-218. 
Hall, R., M. Edelman, S.M. Borras Jr., I. Scoones, B. White and W. Wolford. 2015. Resistance, acquiescence or incorporation? An introduction to land grabbing and political reactions from below. Journal of Peasant Studies 42(3-4): 467-488.

Hernández Cruz, R., E. Bello Baltazar, G. Montoyagómez and E.I.J. Estrada Lugo. 2005. Social adaptation: ecotourism in the Lacandon Forest. Annals of Tourism Research 32(3): 610-627.

Herrera, C. 2011. El turismo de aventura, opción de indígenas para corregir desigualdades, dice Calderón. La Jornada. [accessed February 18, 2015]. http://www.jornada.unam.mx/2011/10/18/politica/015n1pol

INE. 2000. Programa de Manejo Reserva de la Biosfera Montes Azules. México: INE, SEMARNAT.

INEGI, 2012. Anuario estadístico del Estado de Chiapas 2012. México: INEGI.

Igoe, D. and D. Brockington. 2007. Neoliberal conservation: a brief introduction. Conservation and Society 5(4): $432-449$.

Instituto de Comunicación Social. Gobierno del Estado de Chiapas. 2014 Comunicado: Comuneros de la Selva Lacandona reciben pago económico por servicios ambientales. [accessed September 19, 2014] http://www.icosochiapas.gob.mx/2014/09/19/comuneros-de-la-selva-lacandona-reciben-pagoeconomico-por-servicios-ambientales/

Legorreta Díaz, M. del Carmen and C. Márquez Rosano. 2014. ¿Es posible la conservación de las áreas protegidas por decreto? Retoso sociopolíticos para la gestión ambiental democrática en las comunidades de Nueva Palestina y Frontera Corozal, Ocosingo, Chiapas. In Díaz Legorreta C., C. Márquez Rosano and T. Trench (eds.). Paradojas de las tierras protegidas en Chiapas. México: UNAM, Universidad Autónoma de Chapingo.

Leyva Solano, X. and G. Ascencio Franco. 2002. Lacandona al filo del agua. México: CIESAS, UNAM and FCE.

Lezama, J.L. 2010. Sociedad, medio ambiente y política ambiental 1970-2000. In Lezama, J.L. and B. Graizbord (eds.). Los grandes problemas de México vol. 4. México: El Colegio de México.

Li, T.M. 2000. Articulating indigenous identity in Indonesia: resource politics and the tribal slot. Comparative Studies in Society and History 42(1): 149-179.

López, I. 2013. Suspendido el programa REDD Plus, dice SEMAHN. El Heraldo de Chiapas. [accessed December 9, 2014]. http://www.oem.com.mx/elheraldodechiapas/notas/n3045308.htm

Mariscal, A. 2006. Pago la SRA 172 millones a lacandones. La Jornada, March 29.

Mariscal, A. 2014. El fin de la hegemonía lacandona en la Selva de Chiapas. Chiapas Paralelo [accessed December 15, 2017] https://www.chiapasparalelo.com/opinion/2014/12/el-fin-de-la-hegemonialacandona-en-la-selva-de-chiapas-columna-destacada-2014/

Mendoza, E. 2012. Gobierno privatizará el oxígeno de la Selva Lacandona. Contralínea. [accessed October 20, 2014]. http://contralinea.info/archivo-revista/index.php/2012/11/11/gobierno-privatizara-eloxigeno-de-la-selva-lacandona/

Mendoza, E. and R. Dirzo. 1999. Deforestation in Lacandonia (southeast Mexico): evidence for the declaration of the northernmost tropical hot-spot. Biodiversity and Conservation 8: 1621-1641.

Milton, K. 1996. Environmentalism and cultural theory. London: Routledge.

Muench, P. 2008. Libro blanco de la selva, Proyecto Desarrollo Social Integrado y Sostenible. Tuxtla Gutiérrez: Secretaría de Desarrollo Social del Gobierno del Estado de Chiapas and Unión Europea.

Navarro Olmedo S., N. Haenn, B. Schmook and C. Radel. 2016. The legacy of Mexico's agrarian counterreforms: reinforcing social hierarchies in Calakmul, Campeche. Journal of Agrarian Change 16(1): 145-167.

Nygren, A. 2006. Representations of tropical forests and forest dwellers in travel accounts of National Geographic. Environmental Values 15(4): 505-525.

O'Brien, K.L. 1998. Sacrificing the forest. environmental struggles in Chiapas. Boulder: Westview Press.

Paladino, S.R. 2005. We are the guardians of the selva: conservation, indigenous communities, and common property in the Selva Lacandona, Mexico. PhD. dissertation. Athens: University of Georgia. 
Perrault, T. 2001. Developing identities: Indigenous mobilization, rural livelihoods, and resource access in Ecuadorian Amazonia. Cultural Geographies 8(4): 381-412.

Porro, N., I. Veiga and D. Mota. 2011. Traditional communities in the Brasilian Amazon and the emergence of new political identities: the struggle of the quebradaeiras de coco de babaçu. Journal of Cultural Geography 28(1): 123-146.

Reik, D.B., A.L. Wilson and D.J. Decker. 2008. Power in natural resource management: an application of theory. Society and Natural Resources 21: 729-739.

Rocheleau, D.E. 2015. Networked, rooted and territorial: green grabbing and resistance in Chiapas. Journal of Peasant Studies 42(3-4): 695-723.

Sarukhán, J. 1991. El último refugio. In Eccardi, F. (ed.). Lacandona, el último refugio. México: Agrupación Sierra Madre S.C. and UNAM.

Simonian, L. 1999. La defensa de la tierra del jaguar. México: CONABIO, INE and IMERNAR.

Sundberg, J. 2002. Conservation as a site for democratization in Latin America: exploring the contradictions in Guatemala. Canadian Journal of Latin American and Caribbean Studies 27(53): 73-103.

Sundberg, J. 2004. Identities in the making: conservation, gender and race in the Maya Biosphere Reserve, Guatemala. Gender, Place and Culture 11(1): 43-66.

Sundberg, J. 2006. Conservation encounters: transculturation in the "contact zone" of empire. Cultural Geographies 13(2): 239-265.

Tejeda-Cruz, C. 2002. Apropiación social del territorio y política ambiental en la Selva Lacandona, Chiapas. El caso de Frontera Corozal, Comunidad Lacandona. Masters dissertation. Mexico: Universidad Autónoma de Chapingo.

Tejeda Cruz, C. 2009. Conservación de la biodiversidad y comunidades locales: conflictos en áreas naturales protegidas en la Selva Lacandona, Chiapas, México. Canadian Journal of Latin American and Caribbean Studies 34(68): 57-88.

Tejeda Cruz, C. and C. Marques Rosano. 2006. Apropiación territorial y aprovechamiento de los recursos forestales en la comunidad Frontera Corozal, Selva Lacandona, Chiapas, México. Geografia Agrícola 37: 79-95.

Trench, T. 2002. Conservation, tourism and heritage: continuing interventions in Lacanjá Chansayab, Chiapas, Mexico. Ph.D. dissertation in Social Anthropology. Manchester: University of Manchester.

Trench, T. 2005. Representaciones y sus impactos. El caso de los lacandones en la selva lacandona. Liminar III (2): 48-69.

Trench, T. 2008a. From "Orphans of the State" to the Comunidad Conservacionista Institucional: the case of the Lacandón Community, Chiapas. Identities: Global Studies in Culture and Power 15(5): 607-634.

Trench, T. 2008b. Regularización de la propiedad en la selva lacandona: cuento de nunca acabar. Gabriel Ascencio Franco Tuxtla Gutiérrez, UNICACH. Revista Pueblos y Fronteras 6: 1-4.

Vadjunec, J.M., M. Schmink and A.L. Greiner. 2011a. New Amazonian geographies: emerging identities and landscapes. Journal of Cultural Geography 28(1): 1-20.

Vadjunec, J.M., M. Schmink and C.V.A. Gomes. 2011b. Rubber tapper citizens: emerging places, policies and shifting rural-urban identities in Acre, Brazil. Journal of Cultural Geography 28(1): 73-98.

Van der Ploeg, J.D. 2010. The peasantries of the twenty-first century: the commoditisation debate revisited. The Journal of Peasant Studies 37(1):1-30.

Villalobos Cavazos, O. 2012. Del Lacandón a las Selva Lacandona. La construcción de una región a partir de sus narrativas y representaciones. Master dissertation. Mexico: Universidad Autónoma de Chapingo. 